\title{
Shopping at Sales ${ }^{1}$
}

Mary N. Harrison ${ }^{2}$

Sale! To many consumers this magic word means bargains galore. . . money saved. . . a treasure hunt. To others, it means crowded stores and picked-over merchandise. Who is correct?

Most people do go to sales, even if only occasionally, in the hope of getting more value for dollars spent. The extensive use of the term "sale" in advertising and retailing is testimony to its effectiveness as a method of selling.

\section{Types of Sales}

Although there are many different kinds of sales, they all can be grouped into two general classifications: promotional and clearance. By recognizing the type of sale, a consumer is better able to anticipate the potential condition of merchandise and the amount of price reduction.

\section{Dispose of Unwanted Merchandise}

There are several different kinds of sales which are designed to get rid of the merchandise that retailers no longer want to keep in stock. As a general rule these types of sales offer the greatest price reductions, but they usually offer the most limited selection of products. They may also offer the greatest opportunity for the shopper to make a very good buy, or a very poor one, depending on the shopper's skills. Sales designed to dispose of unwanted merchandise include:

- Clearance sales are designed to "clear out" leftover seasonal merchandise, shopworn items, and those that are damaged or are one-of-a-kind.

- Close-out sales are used to get rid of merchandise which will no longer be carried, or a line of products that the manufacturer is discontinuing. (Be sure the item is not being discontinued because of a basic design flaw.)

- Going-out-of-business sales are held when a store is closing (discontinuing business). This often is due to financial problems, but can be for other reasons.

- Disaster sales are usually held following a disaster such as flooding, a fire, hurricane, tornado, or other major problems. Frequently the merchandise is damaged.

- Inventory sales are designed to reduce the quantity of merchandise in stock. These sales are often held near the time a store is required to take

1. This document is Fact Sheet FCS 5019, a series of the Department of Family, Youth and Community Sciences, Florida Cooperative Extension Service, Institute of Food and Agricultural Sciences, University of Florida. Revised: June 2005. First Published: April 1982. Please visit the EDIS Web site at http://edis ifas.ufl.edu

2. Mary N. Harrison, professor; Reviewed by Elizabeth Bolton, professor, both of the Department of Family, Youth and Community Sciences, Cooperative Extension Service, Institute of Food and Agricultural Sciences, University of Florida, Gainesville FL 32611.

The Institute of Food and Agricultural Sciences (IFAS) is an Equal Opportunity Institution authorized to provide research, educational information and other services only to individuals and institutions that function with non-discrimination with respect to race, creed, color, religion, age, disability, sex, sexual orientation, marital status, national origin, political opinions or affiliations. U.S. Department of Agriculture, Cooperative Extension Service, University of Florida, IFAS, Florida A. \& M. University Cooperative Extension Program, and Boards of County Commissioners Cooperating. Larry Arrington, Dean 
inventory for tax purposes. Since retailers pay taxes on their inventories, some prefer to reduce their inventory by having a sale and passing the savings (from lower taxes) to their customers. Sometimes a store will overbuy, and then hold a sale to reduce the amount of merchandise on hand.

\section{Stimulate Consumer Buying}

Promotional sales are quite varied, but all of them use price reductions to coax customers to buy. A promotional sale may be a storewide sale, or it can be for a specific product or service. Generally, promotional sales offer moderate price reductions and have a reasonably adequate supply of merchandise available. Sales designed to stimulate business by enticing the consumer to buy include:

- Seasonal sales are built around merchandise traditionally placed on sale at specific times of the year (for example, white sales). Seasonal sales are also held at the time of special events such as Easter, Christmas, and the beginning of school when special types of merchandise are in high demand.

- Private sales are confined to a store or to a chain whose credit card holders or customers are notified several days before the sale is announced to the public. These sales promote store loyalty by first offering price reductions to the store's customers.

- Anniversary sales which commemorate the founding of the store with general storewide price reductions.

- One-day sale or holiday sales feature markdowns for special holidays such as St. Valentines Day, Memorial Day, and Labor Day.

- Special purchase sales offer merchandise that a store's buyer has obtained from a manufacturer or wholesaler at a cut-rate price. The special purchase may be a manufacturer's overrun, seconds or irregulars, or be merchandise ordered by another store that went out of business before its order was delivered. It may or may not be of the quality usually carried by the store.

- Introductory sales introduce a new product, service, or store. These sales help consumers learn about the availability of specific goods and/or services.

- Stimulation sales are designed to increase sales volume during periods of slow movement. They are often held during summer months when customers are away on vacation instead of shopping, or during bad winter weather when shoppers stay home. Merchants need enough sales volume to pay their employees salaries and their other operating expenses.

\section{Sales Methods}

The names given to sales are numerous and interesting, and in some instances indicate the method of selling. For example: a "moonlight or midnight madness" sale indicates the sale is at night. Sale items may be clearance merchandise offered at a low price, or promotional merchandise. Sidewalk sales usually display merchandise on racks and tabletops on sidewalks outside the store or in the corridor of the mall. Many shoppers think merchandise placed on a table or in a bin is reduced in price. It may or may not be. It is wise to compare prices carefully with other merchandise in stock. Some sales are by invitation only or require an admission ticket. This may be a way of offering special customers the first opportunity at price reductions. In other cases it is an illusion to stimulate buying.

\section{Annual Sales Calendar}

Although sale calendars are routinely published, they are often not completely reliable. Most stores have sales often to stimulate the movement of goods. If business drops off, a store will hold a sale to attract customers and to bring in revenue needed for expenses. If a new shipment of merchandise is scheduled to arrive soon, a store may have a sale to dispose of the merchandise on hand, thus making room for the new order. Unexpected expenses or an upcoming bill can cause a retailer to have a sale to raise the money. Sales are used to raise money for expansion or remodeling. A downturn in the economy can mean slow business and result in a promotional sale. Specialty stores that deal in high-priced merchandise such as furniture, jewelry, and appliances are especially hard hit by a slow economy. 
Many products such as appliances and motor vehicles have a model year. Retailers of these products conduct sales just prior to the introduction of new models.

The traditional sale calendar is listed below. However, the local marketing conditions and each store's unique situation are a more reliable indicator of the frequency, time and type of sales, and the amount of price reduction. (See Table 1.)

Table 1.

\begin{tabular}{|c|c|}
\hline \multicolumn{2}{|r|}{ SALES CALENDAR } \\
\hline January & $\begin{array}{l}\text { white sales, appliances, air } \\
\text { conditioners, clothing, Christmas } \\
\text { merchandise. }\end{array}$ \\
\hline February & $\begin{array}{l}\text { furniture, rugs, china, mattresses, } \\
\text { glassware, silver. }\end{array}$ \\
\hline March & $\begin{array}{l}\text { garden supplies, luggage, spring } \\
\text { clothing. }\end{array}$ \\
\hline April & after Easter sales, clothing. \\
\hline May & white sales, clean-up, fix-up supplies. \\
\hline June & $\begin{array}{l}\text { women's ready-to-wear, TVs, } \\
\text { refrigerators, used cars, floor covering. }\end{array}$ \\
\hline July & $\begin{array}{l}\text { shoes clothing, bathing suits, } \\
\text { refrigerators, used cars, floor covering }\end{array}$ \\
\hline August & $\begin{array}{l}\text { furniture, white sales, camping } \\
\text { equipment. }\end{array}$ \\
\hline September & $\begin{array}{l}\text { back-to-school supplies, } \\
\text { housewares. }\end{array}$ \\
\hline October & cars, coats, lingerie. \\
\hline November & coats, pre-Christmas items. \\
\hline December & toys, gift items. \\
\hline
\end{tabular}

\section{Laws and Regulations Relating to Sales}

It is illegal to advertise foods or services without the intention of selling them. This regulation is specifically designed to prohibit bait-and-switch tactics (enticing a customer to a store for a product advertised at a low price with the intent to sell a more expensive one.)
A company or store can't claim to be going out of business "closing forever," unless it is true.

It is illegal to advertise items for sale if they are not available for sale. A company advertising products to be on sale should have enough available to supply a reasonable demand unless the advertisement specifically states that the supply is limited or consist of one-of-a-kind items. (Although this regulation was specifically written for supermarkets, most legal authorities extend the interpretation to include other kinds of retail establishments.)

Prices must be no higher than those stated in the ads. They may be lower. If a mistake is made by the advertiser (newspaper, radio or T.V.), the seller is not held liable for the advertiser's mistake.

\section{Cautions for Shoppers}

Shoppers attending sales should be especially cautious to be sure they get their money's worth.

- Be sure to comparison shop-even at sales. Merchandise at some stores will cost more, even when on sale, than the same-or similar-merchandise at other stores.

- Ask yourself: Why did this merchandise not sell at regular price? Was it over-priced? Is there a defect? If so, how will the defect or other problems affect this particular product?

- Is the price reasonable? Was the product over-priced and then marked down? If that is the situation, it is not a bargain.

- Some hang tags show two prices, one of which is the sale price. Is the other price the prior selling price or a "suggested retail price?" Look for the items regular selling price not the suggested price.

- Would you consider buying the product if it were not on sale? Poorly constructed products or odd designs are not bargains.

- Usually sale merchandise can't be returned or exchanged (unless it was sold as first quality and turns out to be defective.) 


\section{Buying Tips}

- For promotional sales it is usually wise to shop the first days of the sale because the selection is better. Prices will not change during the sale.

- If the sale is a clearance sale, the price reduction usually is larger than it is during promotional sales. The best selection is at the beginning of the sale; however, the best prices are often found during the last few days.

- Comparison shop before buying. Compare quality, usefulness, and price.

- Be sure all warranty information and care instructions are included with the product.

- Carefully inspect for damage and quality of construction.

- Recognize that the excitement of buying at a sale is contagious. Don't buy just because others are buying. A price reduction is no bargain if the product is not needed.

- If a purchase is likely to need service and the sale is a closeout sale, find out who will provide the service and warranty work.

\section{Other Forms of Price Reductions}

There are a number of other types of price reductions. Some of these are listed below.

- Cents off - price reductions given by the manufacturer or distributor. There are specific regulations governing this area. A product can be sold only 6 months out of a year with a cents-off offer. At other times it must sell at regular price.

- "Specials" or loss-leaders - inexpensive, commonly used items are sold at a reduced price to attract customers. Usually they require the consumer to purchase other merchandise to be eligible to take advantage of the special.

- Introductory offer - merchandise that is new, or new to the marketing area. Price reductions can be for no more than 6 months out of the year. (The law requires products to be new, improved, or introduced to a new marketing area to be sold as an "introductory offer.")

- Coupons and refunds are other ways of taking advantage of price reductions. 